\title{
STRATEGIC CORPORATE SHIFTS TOWARDS ADAPTIVE FOOD GOVERNANCE UNDER ENVIRONMENTAL CHANGE: A COMPARISON BETWEEN SOUTH AFRICAN AND BRAZILIAN RETAILERS
}

\author{
Laura Pereira \\ DPhil student, School of Geography and the Environment, University of Oxford \\ laura.pereira@ouce.ox.ac.uk). \\ Yuna Souza dos Reis da Fontoura \\ Doctoral Candidate in Management from EBAPE/FGV \\ Yuna.Fontoura@fgv.br \\ Carlos Frederico Vanderlinde Tarrisse da Fontoura \\ Doctoral Candidate in Management from PUC-RIO \\ cfontoura@iag.puc-rio.br and
}

\begin{abstract}
Governance in the food system has become a key topic of discussion in light of the 2007-08 food price crisis. Of special importance has been the shift to include the role that non-state actors are likely to play in achieving food security under global environmental change (GEC). This paper aims to compare private sector food system governance trends in two emerging economies, Brazil and South Africa. It focuses on practices around adaptation, an area largely neglected in climate change discussion, yet a critical factor in coping with the societal consequences of GEC. This study identifies several processes, particularly within the retail sector, that could indicate normative mechanisms through which 'good governance' can be translated into practice.
\end{abstract}

Key words: Food security, global environmental change, adaptation, corporate governance, Brazil, South Africa.

\section{ESTRATÉGICAS CORPORATIVAS PARA UMA GOVERNANÇA DE ALIMENTOS ADAPTATIVA À MUDANÇA AMBIENTAL: UMA COMPARAÇÃO ENTRE VAREJISTAS SUL-AFRICANOS E BRASILEIROS}

\section{RESUMO}

Governança no sistema alimentar tornou-se um dos principais tópicos de discussão, à luz da crise de 2007 a 2008 nos preços dos alimentos. Um aspecto importante foi a mudança para incluir o papel que os atores não estatais são susceptíveis de desempenhar para atingir a segurança alimentar na mudança ambiental global - MAG. Este trabalho tem como objetivo comparar as tendências de governança corporativa no setor privado de alimentos de duas economias emergentes, Brasil e África do Sul. A pesquisa se concentra em práticas em torno de adaptação, uma área muito negligenciada na discussão sobre mudança climática, mas um fator crítico para lidar com as consequências sociais da MAG. Este estudo identifica vários processos, nomeadamente no setor de varejo, que poderiam indicar os mecanismos normativos por meio do qual "boa governança" pode ser traduzida em prática.

Palavras-chave: Segurança alimentar, mudança ambiental global,adaptação, governança corporativa, Brasil, África do Sul. 


\section{INTRODUCTION}

A dominant shift in food system governance from the public to private sector has taken place, bringing with it questions of the role that non-state actors are likely to play in food system adaptation to global environmental change (Liverman et al., 2009). Food security is underpinned by the system through which food is produced, processed, distributed, sold and consumed and is thus threatened when this food system is stressed (Gregory et al., 2005). Over the past decade the number of undernourished people worldwide has steadily climbed upward, exacerbating the problems of an already fragile global food system. The impact of global climate change is expected to be a major additional stressor in the future (FAO 2009).

The 2007-08 global food price crisis, followed by the 2008 financial crisis, has sparked discussions around issues of governance and strengthening governance mechanisms for world food security (FAO 2009). Under these discussions, the role of business in food security has been identified as vital, resulting in a shift towards including the private sector as a key player in attaining food security goals such as the first Millennium Development Goal (MDG) of reducing extreme poverty and hunger. A key document highlighting this is the UN private sector food sustainability guide, which provides guidelines on where in the food system action is required and how businesses at all points along the value chain can contribute towards achieving sustainability in the food system with the ultimate objective of global food security (UN 2009). Some authors have further proposed that global environmental challenges (such as climate change) have now become business problems that directly affect companies operations, not just shareholder investment and that dealing with them calls for a strategist's approach rather than that of a philanthropist (Porter and Reinhardt 2007).

When analyzing corporate strategies around social and environmental issues like food security and climate change, it is necessary to embed this within regional and national conceptions of the role of business in dealing with these issues, which often stem from ideas rooted in Corporate Social Responsibility (CSR). CSR in Latin America has been shaped by two trends. The first is based on the region's Catholic traditions of philanthropy where companies have stepped up to the plate in order to fill in the gap when governments have lacked resources to invest in societal and sometimes environmental problems (Puppim de Oliveira 2006). A newer conception of CSR in the region has been modelled along the lines of Western based companies looking to improve their image, particularly within their supply chains and has thus been heavily influenced by INGOs, the headquarters of MNCs and multilateral institutions (Haslam in Peinado-Vara 2004: 62). These foreign roots are not necessarily appropriate for the Latin American (or arguably the African) context and so there has been a call for developing a model of CSR that addresses local issues- that are often more societal than environmental- as well as strengthening governments' capacity (Schmidheiny 2006).

Regionally, Brazil has led the game in redefining the concept of CSR since the development of ETHOS ${ }^{1}$ in 1998 (Correa et al 2004) and has also spearheaded non-financial reporting (Araya 2006). In Africa, South African companies dominate as they play a similar role on the continent to what MNCs play globally (Malan 2005). Although this has led to these companies adopting a more African approach to CSR, they still face resistance in many African countries (Malan 2005).

This paper provides an analysis of corporate governance for food security under climate change in the retail sectors of Brazil and South Africa by combining both academic conceptualisations of governance as well as ideas of governance as it is practised within corporations. We anchor the analysis in the Earth System Governance (ESG) approach focussing on adaptation and using this, we investigate the main proposals for food security governance under climate change, identify significant steps that are being proposed in the retail sector and compare these processes and their proposed impacts in the two countries. Through this process, we aim to

\footnotetext{
${ }^{1}$ Instituto Ethos de Empresas e Responsabilidade Social (ETHOS) has 780 affiliated companies throughout Brazil and is based in São Paulo.
}

Revista de Gestão Social e Ambiental - RGSA, São Paulo, v. 7, n. 1, p. 101-113, jan./abr. 2013. 
start bridging the divide between theoretical conceptions of governance involving the private sector and its implementation in corporate governance.

\section{CONCEPTS OF 'GOVERNANCE'}

According to the United Nations Development Program (UNDP), governance is defined as a system of values, policies and institutions by which society organizes collective decision-making and the political, economic, socio-cultural and environmental actions occur through the interaction between state, civil society and the private sector (UNDP 2002). It further comprises the mechanisms, processes and institutions through which citizens and organized groups articulate their individual interests, assess their differences and exercise their legal rights and obligations (UNDP 2002). This is oriented towards a particular understanding of governance and can be linked to progressive developments from a hierarchical 'management' approach to more 'adaptive' governance (e.g. see Brunner et al 2005). However, there are various types of governance even within this interpretation, all of which are ultimately influenced by international pressures and trends (UNECA 2007). Otobo (2000) conceptualizes these as a set of concentric rings, with the outer ring being political governance providing economic orientation and infrastructure, the next ring being economic governance providing the context with corporate governance lying in the centre. As such, corporate governance draws from trends in other spheres of governance, but at the same time functions within parameters specific to the corporation such as goals oriented towards profit-generation and investment.

This is encapsulated in the definition of corporate governance as it is more widely practiced: as "a set of relationships and arrangements between company's management, its board, its shareholders and other stakeholders" (OECD 2004: 11, see the rest of the document for other definitions). It provides the structure and mechanisms for strengthening investor confidence by tracking company performance across a spectrum of indicators and is therefore important not only for achieving company goals, but also for the smooth functioning of the market economy (OECD 2004). The primary concern of corporate governance has been to protect shareholders from managers exercising their power to further their own interests and not those of the equity holders (Tosi 2008). However, the notion of accountability has been extended beyond these narrow interests to include those of other stakeholders (Collier and Roberts in Roussouw et al 2002). According to Roussouw et al (2002), this can be further expanded to a view of the company as a social institution that has responsibilities towards those normally excluded from the corporate vision such as the disadvantaged and the environment, putting pressure on boards to account for more than just shareholder interests.

Although there are other ways in which governance has been conceptualized in order to take these factors into account (e.g. see Gereffi et al., (2005) for global value chain governance), in this paper we are concerned with what trends are driving this normative extension of corporate governance. Internationally, initiatives like the Global Reporting Initiative (GRI) pioneered in 1997, which has generated international best practice norms around sustainability reporting and the establishment of the World Business Council for Sustainable Development (WBCSD) are examples of this shift towards an inclusive understanding of corporate governance. In our focus countries of Brazil and South Africa incorporation of these norms has led to certain trends towards adaptive food governance within corporate governance.

This analysis is rooted in ESG, which consists of a broad and inter-related system of formal and informal regulations through which a diverse network of actors participate in formulating a normative conception of sustainable development (Biermann et al., 2009). The governance process is analyzed from the perspective of the interrelated problems of the architecture involved, the role of agents in the structure, the importance of adaptation to environmental changes, the need to ensure accountability and the examination of ways of allocation (Biermann et., al 2009). ESG has its foundations in systems thinking which is employed when addressing "complex problems with

Revista de Gestão Social e Ambiental - RGSA, São Paulo, v. 7, n. 1, p.101-113, jan./abr. 2013. 
multi-causality resulting from interactions among interdependent components" (Ericksen 2008: 237). As food systems are characteristically entities in which human and natural systems interact, Ericksen (2008) suggests that food systems can best be conceptualized as socio-ecological systems (SESs). This frames environmental change consequences for food systems in the context of socioeconomic and political change in order to understand the effects of the multiple stresses that interact with food systems, which can sometimes make them or their components vulnerable (Ericksen 2008). Although a systems approach deals with the complex nature of food systems, it raises a related issue of defining the historically contested concepts of system vulnerability, adaptive capacity and resilience.

The ability to undergo the changes required to maintain food system resilience under future impacts will include an ability a) to adjust to a change, b) to buffer potential damages limiting its ability provide food security, and c) to take advantage of opportunities offered by this change (IPCC 2007). Adaptive capacity is the most dynamic element of vulnerability because it is where interventions can take place through strategic management and the anticipatory creation of new structures, policies and mechanisms to cope with projected changes. Recent work by Bohle et al., (2009) on the informal rules governing the urban food sector in Dhaka, Bangladesh combines the concept of adaptive capacity with ESG and has defined adaptive food governance as the interrelated systems of formal and informal rules and networks that are set up to guide the food system to adaptability and resilience under problems of complexity, uncertainty, fragmentation and violence inherent in a system under "double exposure." ${ }^{2}$ "This is premised upon a normative context of food security where food is a human right. (Bohle et al., 2009: 53).

However translating concepts like adaptive capacity from systems thinking for implementation in corporate governance is difficult. Therefore, we aim to identify concrete examples where private sector responses to vulnerabilities in the food system can be indicative of adaptive capacity and illustrate how these adaptive food governance trends could be further developed.

\section{THE FOOD RETAIL SECTOR IN BRAZIL}

The history of the food retail sector in Brazil demonstrates the dynamism of this sector. When the idea of supermarkets first arrived in Brazil, consumers were surprised by a format where they could wander through corridors full of different products such as fruits, vegetables, meat and processed foods, all in a single location. The first supermarket was built in 1950 and by the end of 1970 there were more than 3000 stores. Even with the pressure from various economic problems such as price freezes, in the 1980s the supermarkets were already Brazil's main food distribution channel with 13646 stores spread throughout the country (Souza, 2002).

The opening of the market started in the 1990s with the entry of major global players such as Sonae (1995), Jerônimo Martins (1999), Royal Ahold (1997) and the American giant Wal-Mart (1995), forced the national companies to compete with them. This started a series of mergers and acquisitions (among national companies and between national and international companies) that consolidated Brazil as a target for global players in this sector (Souza 2002). Today, the Brazilian food retail sector is composed of more than five hundred companies, but most of the revenue is concentrated in a few major players. A survey from the Brazilian Supermarkets Association analyzing the twenty biggest supermarkets shows that the three major players (Walmart, Carrefour and Pão de Açúcar) are responsible for approximately $75 \%$ of the revenue currently topping $\mathrm{R} \$ 80$ billion (ABRASNET 2010). In the 2009 Stores Global Powers of Retailing report, these companies placed $1^{\text {st }}, 2^{\text {nd }}$ and $106^{\text {th }}$ respectively. With $85 \%$ of consumption happening through this channel, the

\footnotetext{
${ }^{2}$ Double exposure is a term used to refer to the impacts that systems face from both global environmental change and globalisation (O'Brien and Leichenko 2000)
}

Revista de Gestão Social e Ambiental - RGSA, São Paulo, v. 7, n. 1, p. 101-113, jan./abr. 2013. 
sector is highly important for both the public and the economy of the country and we can also infer that severe impacts in its supply chain could lead to food access issues and a major loss of taxes.

Therefore, studying how climate change impacts are dealt with by these actors, and how the government includes this sector in its Climate Change National Plan, is essential for understanding food security in the country where the main strategy is the government-led 'Zero Hunger' program which provides support to around a third of Brazil's population (FAO 2009). In this document, although the issue of food security is acknowledged, the assessment of impacts and mitigation/adaption proposals only contemplate the producers.

\section{THE FOOD RETAIL SECTOR IN SOUTH AFRICA}

The Latin American food retail story that started in the mid 1990s, which featured giant waves of FDI by global multinationals such as Ahold, Walmart, and Carrefour, has only just begun in Africa and there are definite pockets growing in southern and eastern Africa (Weatherspoon and Reardon 2003; Arda 2007). According to a study by Reardon et al (2003), post-Apartheid South Africa has become the African front-runner with roughly a 55\% share of supermarkets in overall food retail. South African retailing is composed of two different sectors: the informal sector comprising hawkers, small stands and spaza shops and the formal sector, which we focus on here. This formal sector consists of large format hyper and supermarkets, smaller superettes and then 'non-major' stores like convenience stores, urban counter and self-serve stores (Weatherspoon and Reardon 2003). The progression of these stores is similar to that of retailers in Argentina and Costa Rica where the format started with supermarkets and then moved to hypermarkets and then convenience stores and geographically started in high-income areas and in major cities and then moved into rural towns and townships where they began to cater to middle and lower income strata (Weatherspoon and Reardon 2003).

South Africa's two top retailers, Pick 'n Pay (1967) and Shoprite Checkers (1979), have approximately $40 \%$ of the sector each and have also invested heavily in other African countries as well as India, Australia and the Philippines (Reardon et al 2003). As Johannesburg Stock Exchange (JSE) listed companies, they ranked $127^{\text {th }}$ and $129^{\text {th }}$ respectively in the 2009 Stores global survey making them relatively important players in the South African economy. The companies completing the large formal retail sector in South Africa are Woolworths and Spar with Massmart and Metcash being the two main wholesalers (Louw et al 2006). With growing urbanisation and a burgeoning middle class, food retailers play a significant role in the country and are prime actors in the agri-food chain for innovation around development issues (Louw et al 2006) and potentially climate change adaptation. That being said, this "rapid rise of supermarkets" has also extended into poor neighborhoods and the new trend in the region is of "supermarkets to the poor" making them important both from a food security perspective, as well as for rural development (Weatherspoon and Reardon 2003: 1).

\section{METHODOLOGY}

This paper uses a two-step procedure. We first provide a synopsis of the concepts of governance and where ESG approach is located relative to traditional ideas of corporate governance. Secondly, we analyse the ongoing actions of six major food retailers in Brazil and South Africa that deal with climate change and food security issues. Our analysis is informed by the food systems group of the ESG project where they focus on food governance that is designed so as to maximize flexibility and adaptation to GEC that draws from local knowledge and institutions that facilitate adaptation at other scales (Biermann et al., 2009). This is done through an analysis of company reports, websites, news articles and interviews with key informants. We then compare the findings for the two countries in order to identify normative trends in governance that could be used to bridge the gap between theoretical and practical conceptions of governance for food security under climate change in emerging economies. 


\section{GOVERNANCE IN THE FOOD RETAIL SECTOR: BRAZILIAN AND SOUTH AFRICAN}

There are interesting elements of contrast between the Brazilian and South African corporate governance, which significantly impact adaptive strategies in the food retail sector. Here we outline some of the key features that define each country's corporate governance strategy and how well equipped it is for adaptively dealing with environmental change in the form of climate change and food security pressures.

From 1950 to 1990 , the Brazilian economy was centered on the domestic market and the government was the main direct investor and regulator of private investments. After 1990, the opening up of Brazilian markets and the privatization of many government-owned companies attracted international investors that brought different governance models and questioned traditional country practices. The economic scenario became more competitive and most of the companies saw the adoption of governance structures as a mean to increase corporate performance (Rabelo and Vasconcelos 2002).

Two key events in Brazilian governance history were the foundation of the Brazilian Institute of Corporate Governance (IBGC) in 1995 and the establishment of ETHOS in 1998 (as mentioned above). The purpose of the IBGC was to be the Brazilian reference of corporate governance and to contribute to the sustainability performance of organizations by influencing agents towards greater transparency, fairness and accountability. The institute published the first version of the Brazilian Code of Best Practices in Corporate Governance in 1999, with revisions in 2001, 2004 and 2009. This set out principles of corporate responsibility and the social function of the company being one that includes the creation of wealth and employment opportunities, encourages scientific development through technology, enhances the qualification and diversity of the workforce and improves quality of life through educational, cultural and care actions and environmental protection (IBGC 2009: 10).

Brazil also has a large history regarding the protection of the environment, although most of it derives from government-led governance implemented through model environmental legislation. As environmental awareness increased, society began to demand a more active participation from companies and to question how sustainable their actions were. In Brazil, this movement culminated with the creation of Bovespa's (Brazilian Stock Exchange) Corporate Sustainability Index which since 2005 functions as an investor tool to indentify companies that are socially responsible, sustainable and lucrative. It is considered that these companies create long-term shareholder value as they are more prepared to face economic, social and environmental risks.

Government leadership is also particularly felt in the climate change discourse and through the Climate Change National Plan (MMA 2008), the Working Group on Climate Change Impacts on Brazil and the Role of the Environment National Council (CONAMA) in the adoption of adaptation measures. They comprise a portfolio of mitigating and adaptive actions in order to reduce, avoid, and eventually adapt to the many impacts of climate change. It is important to highlight that mitigation is still regarded as the highest priority because it is the only means through which to slow down the impacts of climate change.

With some of the effects of a changing climate already becoming evident, the need for specific adaptive actions is becoming increasingly important. Even though most of the actions stem from the Government, it is possible to identify some being led by the private sector. Through the analysis of the sustainability reports of the leading food retailers in Brazil (Grupo Pão de Açúcar, Carrefour and Walmart), we infer that they are already following the recommendations set out in the fourth Brazilian Code of Corporate Governance as they confront the issue of corporate responsibility in all of their social and environmental projects. Unfortunately, the retail sector appears to follow the governmental National Plan strictly as they focus only on building adaptive capacity through the promotion of sustainable development and neglect any specific adaptive actions necessary to ensure food security in the country.

Revista de Gestão Social e Ambiental - RGSA, São Paulo, v. 7, n. 1, p. 101-113, jan./abr. 2013. 
The South African government similarly has the 2004 Climate Change Response Strategy with sector specific plans for climate change mitigation and adaptation. The Climate Change Policy and White Paper is due by the end of 2010 and is aimed at building on a broad understanding of what a whole range of stakeholders can do to reduce GHG emissions. This document is clearly focussed on mitigation, which is indicative of the fact that at the government level, although the importance of taking action on climate change is recognised, progress is slow. However, at the business level, much more cutting-edge activity can be discerned. This private sector-led response (in contrast to Brazil's government centred approach to climate change) has its roots in how corporate governance has developed not only in South Africa, but also on the continent.

There is a widely held belief that good corporate governance can result in economic success and long-term sustainability (Armstrong in Roussouw 2005). However, in Africa despite the recognition of the need for accountability, transparency and market discipline especially in order to attract foreign investment and join the global community, very few mechanisms are available to instigate this shift. There are few incentives to join stock exchanges, few regulatory frameworks exist and most State-owned enterprises set a pretty bad example of corporate governance- although post IMF structural adjustment privatisation did not fare any better (Roussouw 2005). The solution lay in the establishment of corporate governance codes and the springboard for this came from the 1994 post-Apartheid revision of corporate governance in South Africa.

South Africa holds a unique position in Africa because of its relatively better-developed and globally-integrated business sector, which gives it a leading role in advancing good corporate governance in the region (UNECA 2007). One of the key developments in corporate governance in South Africa has been the establishment of the King Code on Corporate Governance (referred to as King I, II and III published in 1994, 2002 and 2009 respectively). This was initiated by the Institute of Directors (IoD) in South Africa and comprises a set of non-legislated principles and guidelines for company reporting in line with the GRI. These are unique because of the distinct situation of governance in South Africa that was situated in a "highly turbulent and fluid context... where South African companies [needed to meet] international corporate standards without neglecting their allegiance to the African continent" (Roussouw et al 2002: 301). Many of the companies facing the tension between adhering to global standards and models of best practice and the local implementation of these ideas, have established governance mechanisms where the messier network of stakeholders and interests is taken into account (Hamann and Kapelus 2005). Recognising and responding to this complexity and enhancing the potential for collaboration between a network of interested parties can lead to more sustainable forms of local governance for companies operating under these circumstances (see Hamann and Kapelus 2005 for examples of this from the mining sector which has been at forefront).

In the attempt to meet on the one hand the requirements of international standards and institutional investors and on the other, Mbeki's concept of the African renaissance and the transformation of South African society, the King codes formulate an inclusive concept of corporate governance which include non-financial measurements as well as ethical and moral considerations (Roussouw et al 2002). The King code and its successors has been assimilated into South African corporate culture and the JSE requires all listed companies to provide a narrative statement on how (and if not, why) they have complied with the principles and as a result South African companies have become regarded as among the best governed in emerging economies by foreign investors (IoD 2009).

The institutionalisation of the governance principles in the King report has meant that the code has become a key mechanism for translating between new normative conceptions of governance into practical standards implementable by company boards. This is clearly evidenced in the latest King Report where 'sustainability' was incorporated as one of the three key aspects of the report: "Most importantly current incremental changes towards sustainability are not sufficient- we need a fundamental shift in the way companies and directors act and organise themselves" (IoD 2009: 9). In our survey of food retailers' sustainability reports, this focus is clearly evidenced with

Revista de Gestão Social e Ambiental - RGSA, São Paulo, v. 7, n. 1, p.101-113, jan./abr. 2013. 
'sustainability' being incorporated as the $7^{\text {th }}$ corporate value of Woolworths, which was also ranked 18 out of 399 South African companies analysed for their uptake of King III.

However corporate action around climate change and food security in South Africa is not limited solely to the codification of normative principles, but has become action-oriented too. In February 2009, a food security forum that comprised an array of stakeholders from government through to academics, NGOs and business was convened in Johannesburg. This came just after the South African food sector had been rocked by allegations of collusion around fixing bread prices, which had led to various companies paying hefty fines after an investigation by the competition commission. Combined with the global food price crisis, the issue of food security in the country was brought into wide focus and the results from the forum showed evidence that a definite shift had occurred in how business recognised its role in ensuring food security in the country. The two retailers that were present (Pick ' $n$ Pay and Woolworths) have shown evident concern to develop their role in promoting sustainable behaviour, not only within their companies, but in the wider community as documented in Table 1.

Below is a summary table of some of the key projects being put in place by the leading food retailers in Brazil (Grupo Pão de Açúcar (GPA), Carrefour (CAR) and Walmart (WAL)) and South Africa (Woolworths (WOL), Pick ' $n$ Pay (PNP) and Shoprite Checkers (SCH)). These all indicate a shift of focus towards sustainability issues, however the level of commitment towards an adaptive food governance varies between the projects:

Table 1 - Retailers' actions regarding sustainability

\begin{tabular}{|c|c|c|c|}
\hline Name & Classification & Governance Trends & $\begin{array}{l}\text { Concepts of Good } \\
\text { Governance }^{3}\end{array}$ \\
\hline $\begin{array}{l}\text { Sustainability Pact } \\
\text { (WAL) }\end{array}$ & $\begin{array}{l}\text { Mitigating } \\
\text { Social } \\
\text { Environmental }\end{array}$ & $\begin{array}{l}\text { Incorporation of environmental and social } \\
\text { issues into the business model }\end{array}$ & $\begin{array}{l}\text { Triple bottom line } \\
\text { Self-regulatory practices } \\
\text { Partnerships }\end{array}$ \\
\hline $\begin{array}{l}\text { Personal } \\
\text { Sustainability } \\
\text { Project (WAL) }\end{array}$ & $\begin{array}{l}\text { Mitigating } \\
\text { Social } \\
\text { Environmental } \\
\end{array}$ & $\begin{array}{l}\text { Dissemination of sustainability concepts } \\
\text { through their application on day-to-day } \\
\text { bases by the company's employees. }\end{array}$ & Awareness raising \\
\hline $\begin{array}{l}\text { Sustainability Index } \\
\text { (WAL) }\end{array}$ & $\begin{array}{l}\text { Mitigating } \\
\text { Environmental }\end{array}$ & $\begin{array}{l}\text { Establishment of a sustainability index to } \\
\text { measure in an objective way de } \\
\text { environmental performance of each } \\
\text { product. Delegated to Arkansas } \\
\text { University. }\end{array}$ & $\begin{array}{l}\text { Triple bottom line } \\
\text { Self-regulatory practices }\end{array}$ \\
\hline $\begin{array}{l}\text { Door-to-door } \\
\text { sustainability } \\
\text { (WAL) }\end{array}$ & $\begin{array}{l}\text { Mitigating } \\
\text { Environmental }\end{array}$ & $\begin{array}{l}\text { Partnership with suppliers seeking to } \\
\text { reduce environmental impact in the } \\
\text { product life cycle (from manufacture to } \\
\text { disposal) }\end{array}$ & $\begin{array}{l}\text { Triple bottom line } \\
\text { Self-regulatory practices } \\
\text { Partnerships }\end{array}$ \\
\hline Green stores (GPA) & $\begin{array}{l}\text { Mitigating } \\
\text { Environmental }\end{array}$ & $\begin{array}{l}\text { Construction of stores with less } \\
\text { environmental impacts following the } \\
\text { LEED (Leadership in Energy and } \\
\text { Environmental Design) and USGB } \\
\text { (United States Green Building Council) } \\
\text { standards. }\end{array}$ & $\begin{array}{l}\text { Triple bottom line } \\
\text { Capacity building }\end{array}$ \\
\hline Food banks (CAR) & $\begin{array}{l}\text { Adaptation } \\
\text { Social }\end{array}$ & $\begin{array}{l}\text { Regular donation of food to five food } \\
\text { banks that reach } 40 \mathrm{k} \text { people. The goal is } \\
\text { to donate to } 20 \text { food banks by } 2011 \text {. }\end{array}$ & $\begin{array}{l}\text { Triple bottom line } \\
\text { Capacity building }\end{array}$ \\
\hline $\begin{array}{l}\text { Sustainable Food } \\
\text { Initiative } \\
\text { (CAR) }\end{array}$ & $\begin{array}{l}\text { Adaptive } \\
\text { Environmental }\end{array}$ & $\begin{array}{l}\text { Creating customer awareness around } \\
\text { sustainability issues in the food supply } \\
\text { chain }\end{array}$ & Awareness raising \\
\hline
\end{tabular}

\footnotetext{
${ }^{3}$ These are modelled on the general concepts and principles of good corporate citizenship and behaviour laid out by UNECA (2007:18).

${ }^{4}$ A term coined by John Elkington (1997) to incorporate the three pillars of sustainable development (social, economic and environmental) into corporate governance parlance
} 


\begin{tabular}{|c|c|c|c|}
\hline $\begin{array}{l}\text { Product } \\
\text { Development (All) }\end{array}$ & $\begin{array}{l}\text { Mitigating } \\
\text { Environmental }\end{array}$ & $\begin{array}{l}\text { Products from own brand are } \\
\text { 'sustainable'. }\end{array}$ & $\begin{array}{l}\text { Triple bottom line } \\
\text { Capacity building }\end{array}$ \\
\hline $\begin{array}{l}\text { Sustainable } \\
\text { Connections } \\
\text { (All) }\end{array}$ & $\begin{array}{l}\text { Mitigating } \\
\text { Adaptive } \\
\text { Social } \\
\text { Environmental }\end{array}$ & $\begin{array}{l}\text { Incorporation of environmental and social } \\
\text { issues into the business model } \\
\text { Partnership with government }\end{array}$ & $\begin{array}{l}\text { Triple bottom line } \\
\text { Self-regulatory practices } \\
\text { Partnerships }\end{array}$ \\
\hline $\begin{array}{l}\text { Eco-efficient } \\
\text { internal processes } \\
\text { (All) }\end{array}$ & $\begin{array}{l}\text { Mitigating } \\
\text { Environmental }\end{array}$ & $\begin{array}{l}\text { Adoption of internal processes that reduce } \\
\text { the environmental impact of the } \\
\text { company's commercial and } \\
\text { administrative activities and reduce usage } \\
\text { of natural resources. }\end{array}$ & Triple bottom line \\
\hline $\begin{array}{l}\text { The Good Business } \\
\text { Journey (WOL) }\end{array}$ & $\begin{array}{l}\text { Adaptive } \\
\text { Mitigating } \\
\text { Social } \\
\text { Environmental }\end{array}$ & $\begin{array}{l}\text { Incorporation of environmental and social } \\
\text { issues into the business model } \\
\text { Broad engagement with all stakeholders }\end{array}$ & $\begin{array}{l}\text { Triple bottom line } \\
\text { Self-regulatory practices } \\
\text { Business partner outreach }\end{array}$ \\
\hline Eduplant (WOL) & $\begin{array}{l}\text { Adaptive } \\
\text { Mitigating } \\
\text { Social } \\
\text { Environmental }\end{array}$ & $\begin{array}{l}\text { Partnership with an NGO (Food and Trees } \\
\text { for Africa) } \\
\text { Building adaptive capacity in } \\
\text { communities through skills provisioning } \\
\text { Focusing on food security holistically and } \\
\text { in the long-term } \\
\text { Utilising current sustainability practices }\end{array}$ & $\begin{array}{l}\text { Triple bottom line } \\
\text { Local capacity-building } \\
\text { Human rights }\end{array}$ \\
\hline $\begin{array}{l}\text { Water Neutral } \\
\text { Scheme (WOL) }\end{array}$ & $\begin{array}{l}\text { Adaptive } \\
\text { Social } \\
\text { Environmental }\end{array}$ & $\begin{array}{l}\text { Partnership with NGO (WWF) } \\
\text { Partnership with government (Working } \\
\text { with water programme) } \\
\text { Long-term ( } 20 \text { year commitment) } \\
\text { Adaptive to climate change as water } \\
\text { scarcity is projected to be a key pressure } \\
\text { on the region }\end{array}$ & $\begin{array}{l}\text { Triple bottom line } \\
\text { Local capacity-building } \\
\text { Partnerships }\end{array}$ \\
\hline $\begin{array}{l}\text { Farming for the } \\
\text { future (WOL) }\end{array}$ & $\begin{array}{l}\text { Adaptive } \\
\text { Environmental } \\
\text { Social }\end{array}$ & $\begin{array}{l}\text { Incorporates whole supply chain } \\
\text { Empowers farmers } \\
\text { All farmers that supply produce and aren't } \\
\text { already organic have signed on to grow } \\
\text { all crops in this way by } 2012 \text {, therefore } \\
\text { impact outside their own supply chain }\end{array}$ & $\begin{array}{l}\text { Triple bottom line } \\
\text { Human capital formation } \\
\text { Business partner outreach }\end{array}$ \\
\hline $\begin{array}{l}\text { Development Fund } \\
\text { (PNP) }\end{array}$ & Social & $\begin{array}{l}\text { Social responsibility initiative developing } \\
\text { capacity in the supply chain }\end{array}$ & $\begin{array}{l}\text { Triple bottom line } \\
\text { Awareness raising } \\
\text { Business partner outreach } \\
\text { Human capital formation } \\
\text { Local capacity building }\end{array}$ \\
\hline $\begin{array}{l}\text { Organic Freedom } \\
\text { Project (PNP) }\end{array}$ & $\begin{array}{l}\text { Adaptive } \\
\text { Social } \\
\text { Environmental }\end{array}$ & $\begin{array}{l}\text { Stakeholder engagement } \\
\text { Creating customer awareness around } \\
\text { sustainability issues in the food supply } \\
\text { chain } \\
\text { Long-term impact on supply chain }\end{array}$ & $\begin{array}{l}\text { Triple bottom line } \\
\text { Local capacity building } \\
\text { Human capital formation } \\
\text { Partnership }\end{array}$ \\
\hline
\end{tabular}

Source: Authors own

In Brazil the top three retailers have many projects geared towards environmental issues, but even though food security is one the government's main concerns (e.g. the Zero Hunger Project), there are less private sector projects focussing on this issue. One of the possible obstacles to private sector action in this regard is that the Brazilian government has a dominant hold over all the adaptation actions in Brazil, indicative in governmental documents like the Climate Change National Plan as well as the role of CONAMA in the adoption of adaptation measures. On the other hand, in South Africa, although there is still relatively little exchange between the public and private sectors, the private sector is encouraged to take the initiative on social and environmental issues. Progressive legislation (E.g. National Environmental Management Act of 1998, Black Economic Empowerment Act of 2003) has also been instrumental in mainstreaming environmental 
and social issues in the country, resulting in the development of sustainable business models that take into account these legislative pressures. Although it is still early days, the different regimes in South Africa and Brazil can provide an example of the relative benefits of voluntary market driven mechanisms versus government led top-down approaches to food governance, and which is more or less adaptive.

Although the sustainability arena is subject to a lot of window-dressing, there is evidence of trends towards 'good governance' in the food retail sector, most notably by Woolworths and Pick ' $n$ Pay. These retailers are committed to sourcing 90-95\% of their fresh produce from the local suppliers and have therefore instituted projects that build the resilience of the overall food supply chain in South Africa through various environmental and social upliftment projects, thereby securing their own interests. An interesting observation is that where there are projects that concentrate on building resilience within communities (thereby increasing adaptive capacity); these focus on the production end of the supply chain rather than on consumers. The only projects that involve consumers are those that raise awareness about climate change and sustainability issues, which is necessary, but only a cursory utilization of the power for change that retailers have on the consumption end of the chain. With increasing urbanization, looking at vulnerable consumers will be vital for any strategy concerned with climate change and food security.

\section{CONCLUSIONS}

This paper presented an analysis of governance for food security under environmental change in the retail sectors of Brazil and South Africa where major governance shifts around climate change and food security have been identified in various studies. In this way, the research used an ESG approach focusing on adaptation, although the overall issue of sustainability became an over-riding theme. As the two host countries of the UN Conference on Environment and Development in 1992 and 2002, Brazil and South Africa are critically placed for spearheading governance around climate change. This study reveals that although progressive steps have been taken, a lot remains to be done in this area.

A key conclusion that can be drawn from this brief analysis is how key events or 'tipping points' are critical is the transfer of 'good governance' norms to corporate governance. In South Africa, the intersection of the high international food prices in 2007/08, the competition commission enquiries in 2008 and the King III report in 2009 created a perfect storm for triggering transformative progress around food security in the private sector. It is therefore necessary to harness the energy around these processes to instigate a focus on climate change adaptation too, making sure that this is not seen as mutually exclusive to mitigation initiatives. The current projects aimed at social upliftment contribute significantly to overall adaptive capacity within the South African and Brazilian food systems, but as yet do not make the necessary links between various pressures to be seen as systemic solutions.

The relevance of these observations is not limited to the two countries under consideration. Two of the three major retailers in Brazil, Walmart and Carrefour, are part of a huge global supply chain and as such they are two of the biggest transnational food corporations of the world. These corporations have considerable potential for enhancing food security under climate change, but are still lagging behind in interpreting the 'adaptiveness' element of ESG into their operations. They therefore have a lot to learn from achievements that have been made in the South African market and then to transfer these internationally, creating industry norms. Further research using more indepth studies around the opportunities and constraints offered by the ESG, climate change and food security discourses to these actors is required in order to construct a framework for establishing an adaptive governance for food security under environmental change. This study showed that these adaptive trends are in evidence, but that they require refinement before they can be considered normative.

Revista de Gestão Social e Ambiental - RGSA, São Paulo, v. 7, n. 1, p. 101-113, jan./abr. 2013. 


\section{REFERENCES}

ABRASNET (Associação Brasileira de Supermercados) (2010). Economia e Pesquisa. Retrieved 22 March 2010 from: http://www.abrasnet.com.br/economia-e-pesquisa.

Araya, M (2006) Exploring Terra Incognita: Non-financial reporting in corporate Latin America. Journal of corporate citizenship, 21, 25-38.

Arda, M. (2007) 'Food Retailing, Supermarkets, and Food Security: Highlights from Latin America' in B. Guha- Khasnobis, S.S. Acharya and B. Davis (Eds.), Food Security New York: Oxford University Press.

Biermann, F., Betsill, M., M., Gupta, J., Kanie, N., Lebel, L., Liverman, D., et al (2009) Earth System Governance: People, Places, and the Planet. Science and Implementation Plan of the Earth System Governance Project. Bonn: IHDP.

Bohle, H.-G., Etzold, B., Keck, M. (2009). Resilience as Agency. IHDP Update, 2, 8-13.

Brunner, R. D., Steelman, T.A., Coe-Juell, L., Cromley, C. M., Edwards, C. M., Tucker, D. N. (2005) Adaptive Governance: Integrating Science Policy and Decision-making. New York: Columbia University Press.

Correa, M.E., Flynn, S. and Amit, A. (2004). Responsabilidad social corporativa en América Latina: una visión empresarial. Santiago de Chile: United Nations, Environment and Development series, 85 .

Elkington, J. (1997) Cannibals with Forks: the Triple Bottom Line of $21^{\text {st }}$ Century Business. Oxford: Capstone Publishing.

Ericksen, P. (2008) Conceptualizing food systems for global environmental change research Global Environmental Change, 18, $234-245$.

FAO (Food and Agriculture Organization) (2009) The State of Food Insecurity in the World. Rome: Author.

Gereffi, G., Humphrey, J., Sturgeon, T. (2005). The Governance of Global Value Chains. Review of International Political Economy, 12, 1, 78-104.

Gregory, P., Ingram, J. S. I. and Brklacich, M. (2005) Climate change and food security. Philosophical Transactions of the Royal Society, 360, 2139 - 2148.

Hamann, R and Kapelus, P. (2005, Summer) Local governance as a complex system: lessons from mining in South África, Mali and Zambia, Journal of corporate citizenship, 18,61-73.

IBGC (Instituto Brasileiro de Governança Corporativa) (2009). Código das Melhores Práticas. Retrieved 1 September 2010 from: http://www.ibgc.org.br/CodigoMelhoresPraticas.aspx.

IoD (Institute of Directors) (2009) The King Code of Governance for South Africa. Johannesburg: Author. 
IPCC (Intergovernmental Panel on Climate Change) (2007) Synthesis Report, International Panel on Climate Change. New York: Cambridge University Press.

Liverman, D., Ericksen, P. and Ingram, J. (2009) Governing Food Systems in the Context of Global Environmental Change IHDP Update 3, 59 - 64.

Louw, A., Vermeulen, H., Kirsten, J. and Madevu, H. (2006) Securing small farmer participation in supermarket supply chains in South Africa. Development Southern Africa 24, 4, 539 - 551.

Malan, D. (2005, Summer) Corporate Citizens, Colonialists, Tourists or Activists? Ethical challenges facing South African corporations in Africa Journal of corporate citizenship 18, 49 - 60. MMA (Ministério do Meio Ambiente) (2008) Plano Nacional de Mudanças Climáticas. Retrieved 23 February 2010 from: http://www.mma.gov.br/estruturas/169/_arquivos/169_29092008073244.pdf,

O'Brien, K., L. and R. Leichenko, M. (2000) Double exposure: assessing the impacts of climate change within the context of economic globalization, Global Environmental Change, 10, 221- 232.

OECD (Organisation for Economic Cooperation and Development) (2004). Principles of Corporate Governance, Paris: Author.

Otobo, E E. (2000) Contemporary External Influences on Corporate Governace: Coping with the Challenges in Africa, (A background paper prepared for the Africa Development Report 2001).

Peinada-Vara, E. (2006, Spring) Corporate social responsibility on Latin America, Journal of corporate citizenship, 21, $61-69$.

Porter, M., E and Reinhardt, F. L. (2007, October) Grist: A Strategic Approach to Climate, Forethought, Harvard Business Review, 85, 10, $22-26$.

Puppim de Oliveira, J.A. (2006, Spring). Corporate citizenship in Latin America: New challenges for business, Journal of corporate citizenship, 21, 17 - 20.

Reardon, T., Timmer, C. P., Berdegué, J. and Barrett, C. B. (2003). The rise of supermarkets in Africa, Asia and Latin America. American Journal of Agricultural Economics 83, 1140 -1146.

Rebelo F, M. and Vasconcelos, F.C. (2002). Corporate governance in Brazil, Journal of Business Ethics, 37, 321-333.

Roussouw G.J., A van der Watt and D.P Malan, (2002). Corporate Governance in South Africa, Journal of Business Ethics, 37, 289-302.

Roussouw G.J., (2005). Business Ethics and Corporate Governance in Africa, Business Society 44, 94.

Schmidheiny, S. (2006, Spring). A view of corporate citizenship in Latin America. Journal of corporate citizenship, 21, 21-24

Souza, W. (2002, September) 50 anos de supermercado no Brasil, Superhiper 28.324, 98-114.

Tosi, Henry, L., Jnr, (2008) Quo vadis? Suggestion for further corporate governance research, Journal of Management Governance, 12, 153-169. 
UN (United Nations) (2009) 'Food Sustainability: a guide to private sector action' Retrieved 28 February 2010 from: www.un.org/millenniumgoals/.../foodsus_guide_EMBARGOED.pdf.

UNDP (United Nations Development Programme) (2002). Overview of Globalisation Worldwide: A Stepping Stone to Improved Governance and Human Development, presented at the $2^{\text {nd }}$ International conference on Decentralisation, Federalism: The Future of Decentralizing States? Manila, Philippines, 25 - 27 July 2002.

UNECA (United Nations Economic Commission for Africa) (2007). An Overview of Corporate Governance and Accountability in Southern Africa. Addis Ababa: Auhtor.

Weatherspoon, D.R. and Reardon, T., (2003). Supermarkets in Africa: Implications for Agrifood systems and the rural poor. Development Policy Review, 2,3, 1 -17.

Data da submissão: 30/09/2011

Data da publicação: 30/04/2013 